\title{
Acetylene Reduction by Beijerinckia under Various Partial Pressures of Oxygen and Acetylene
}

\author{
By E. D. SPIFF* AND C. T. I. ODU \\ Department of Agronomy, University of Ibadan, Nigeria
}

(Received 28 March 1972)

SUMMARY

Acetylene reduction by Beijerinckia indica in shaken liquid cultures increased with increase of $p \mathrm{C}_{2} \mathrm{H}_{2}$ up to $0.74 \mathrm{~atm}$. Acetylene reduction was linear for at least $40 \mathrm{~min}$. The oxygen partial pressure also affected activity with most acetylene reduction at a $p \mathrm{O}_{2}$ of 0.15 atm for liquid cultures grown in air.

\section{INTRODUCTION}

The reduction of acetylene to ethylene (Dilworth, I966; Schöllhorn \& Burris, I966) is now widely used as an index of biological nitrogen fixation (e.g. Stewart, Fitzgerald \& Burris, I967; Hardy, Holsten, Jackson \& Burns, I968; Spiff \& Odu, I972). Drozd \& Postgate (1970) have reported that the oxygen sensitivity of the Azotobacteriaceae can lead to a false assessment of nitrogenase activity by the acetylene reduction test. We report here that different partial pressures of acetylene and oxygen greatly affect the level of acetylene reduction by Beijerinckia, a nitrogen-fixing bacterium found in some acidic tropical soils.

\section{METHODS}

Beijerinckia was obtained from the American Type Collection as Azotobacter indicum 9037. Cultures for subsequent inoculation were grown in $500 \mathrm{ml}$ conical flasks, containing $100 \mathrm{ml}$ of medium, at $30^{\circ} \mathrm{C}$ on a reciprocating shaker (I 50 strokes $/ \mathrm{min}$ ). The medium contained: $\mathrm{KH}_{2} \mathrm{PO}_{4}$, I.0; sucrose, $20.0 ; \mathrm{MgSO}_{4} \cdot 7 \mathrm{H}_{2} \mathrm{O}, 0.5 ; \mathrm{Na}_{2} \mathrm{MoO}_{4}, 0.02$; ferric citrate, 0.09 ; in $\mathrm{g} / 1$ distilled $\mathrm{H}_{2} \mathrm{O}, \mathrm{pH} 5.5$. The sugar and phosphate were autoclaved separately and added just before inoculating the flasks.

Nitrogenase activity was measured by the acetylene reduction technique: $5 \mathrm{ml}$ serum bottles equipped with gas-tight rubber stoppers were evacuated, flushed (using a vacuum line) several times with high purity argon and refilled with the desired partial pressure of oxygen and acetylene and then with argon to I atm, the calculated volume of the gases being injected directly into the bottles with a plastic disposable syringe. Three replicate vials were used for each treatment as well as a blank without added culture, to determine the level of ethylene contamination in the added acetylene. A, $\mathrm{O}_{2}$ and $\mathrm{C}_{2} \mathrm{H}_{2}$ were obtained as high purity cylinder gases (Matheson Co., U.S.A.) and were used without further purification. A I ml sample of Beijerinckia culture (or of water for blanks) was usually injected to initiate the

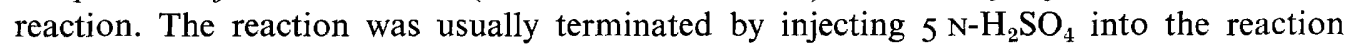
mixture.

The bottles were incubated in a $30{ }^{\circ} \mathrm{C}$ water bath with reciprocal shaking ( 152 strokes/ $\mathrm{min}$ ). The ethylene produced was measured with a Varian aerograph model $600 \mathrm{D}$ gas

* Present address: College of Science and Technology, Port Harcourt, Nigeria. 


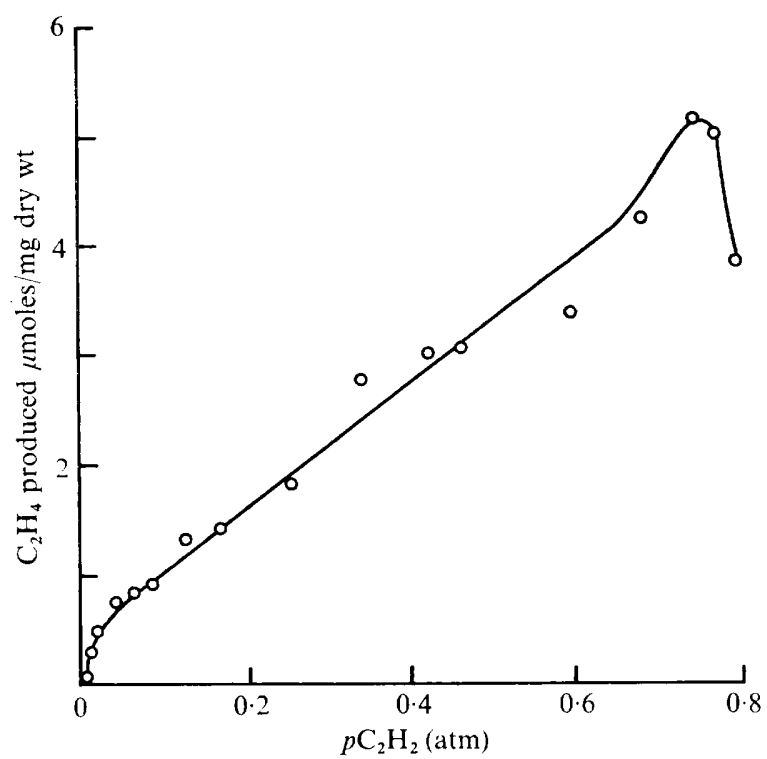

Fig. I. Ethylene production by Beijerinckia incubated at various partial pressures of acetylene for $30 \mathrm{~min}$. The gas phase contained $20 \% \mathrm{O}_{2}, \mathrm{C}_{2} \mathrm{H}_{2}$ as indicated and $\mathrm{A}$ to $\mathrm{I}$ atm.

Table I. Effect of $\mathrm{pO}_{2}$ on $\mathrm{C}_{2} \mathrm{H}_{4}$ production by Beijerinckia in liquid culture

\begin{tabular}{ccccccccc}
\multicolumn{8}{c}{ Vials contained $\mathrm{pC}_{2} \mathrm{H}_{4}$} & 0.2 atm., balance A. \\
0 & 0.05 & 0.1 & 0.15 & 0.20 & 0.25 & 0.30 & 0.40 & 0.50 \\
& \multicolumn{8}{c}{$p \mathrm{O}_{2}$ (atm.) } \\
390 & 480 & 565 & 646 & 437 & 332 & $24 \mathrm{I}$ & 232 & 63
\end{tabular}

chromatograph equipped with a hydrogen flame ionization detector and a $3 \mathrm{~mm} \times 2.5 \mathrm{~m}$ aluminium column packed with Porapak $\mathrm{R}$; the gas sample, usually $\mathrm{I} \mathrm{ml}$, being withdrawn from the bottles and injected directly into the gas chromatograph.

\section{RESULTS}

The relationship between the partial pressure of acetylene and the amount of ethylene produced for Beijerinckia was irregular (Fig. I). Ethylene production increased with increasing acetylene levels until $p \mathrm{C}_{2} \mathrm{H}_{2}$ of 0.74 atm. Nitrogen fixation by cell-free extracts of Azotobacter vinelandii increased as the $\mathrm{pN}_{2}$ increased to $0.5 \mathrm{~atm}$ (Strandberg \& Wilson, 1967).

Ethylene production was measurable after $5 \mathrm{~min}$ and increased linearly for at least $40 \mathrm{~min}$. Crude cell-free extracts of Beijerinckia incubated with suitable cofactors reduced acetylene, and maximum activity was obtained with a $p \mathrm{C}_{2} \mathrm{H}_{2}$ of about $0.04 \mathrm{~atm}$. The specific activity was considerably affected by the partial pressure of acetylene in the gas phase.

Beijerinckia cultures were assayed for their capacity to reduce acetylene under various $p \mathrm{O}_{2}$ levels. The oxygen and acetylene $(0.2 \mathrm{~atm})$ were injected directly into an evacuated bottle and argon added to one atmosphere. Table I shows that considerable acetylene reduction took place under anaerobic conditions for short periods (30 min). Maximum acetylene reduction occurred at a $\mathrm{pO}_{2}$ of $0.15 \mathrm{~atm}$ and was negligible at oxygen tensions greater than $0.50 \mathrm{~atm}$. 


\section{DISCUSSION}

The effect of $p \mathrm{C}_{2} \mathrm{H}_{2}$ is an important consideration in the acetylene reduction technique. Schöllhorn \& Burris (1967), using cell-free preparations from Azotobacter vinelandii and Clostridium pasteurianum, obtained a $K_{m}$ of $0.0 \mathrm{I}$ atm for acetylene reduction, similar to that obtained by Dilworth (I966). This was, however, low compared with a value of about $0 \cdot \mathrm{I}$ atm $\mathrm{N}_{2}$ for nitrogen fixation. Schöllhorn \& Burris only reported using partial pressures of acetylene up to 0.I atm. Drozd \& Postgate ( 1970 ) obtained $K_{m}$ values of $0.0028 \pm 0.0005 \mathrm{~atm}$ for Azotobacter chroococcum. Hardy et al. (1968) obtained a Michaelis constant of 0.003 to 0.008 atm $\mathrm{C}_{2} \mathrm{H}_{2}$ with an average of $0.006 \mathrm{~atm}$ for Clostridium pasteurianum, while for $A$. vinelandii incubated at $0 . \mathrm{I}$ atm or less $\mathrm{C}_{2} \mathrm{H}_{2}$ they obtained 0.003 to $0.006 \mathrm{~atm}$ with 0.005 as average but showed 'an as yet unexplained increase in the rate of $\mathrm{C}_{2} \mathrm{H}_{2}$ reduction at $0 \cdot 2$ and $0.5 \mathrm{~atm}$ of $\mathrm{C}_{2} \mathrm{H}_{2}$ '.

Our present results suggest that the effect of $p \mathrm{C}_{2} \mathrm{H}_{2}$ on acetylene reduction by Beijerinckia should be examined further. The amount of acetylene in the gas phase used by various workers has varied considerably. Care should be taken to see that sufficient $\mathrm{C}_{2} \mathrm{H}_{2}$ is present to give maximum reduction rates.

The oxygen sensitivity of the Azotobacteriaceae is well known. Postgate (I969) and Dalton \& Postgate (1969) have suggested that the high respiratory rate of Azotobacter protects functional nitrogenase from damage by oxygen. The results reported here agree with the view that nitrogen fixation by aerobic organisms may occur under partially or fully anaerobic conditions in natural environments.

This work was carried out in the Department of Biochemistry, University of Wisconsin, Madison, U.S.A. We thank Professor R. H. Burris for providing facilities most generously and for his interest. Grateful thanks are also due to the the University of Ibadan for financial support which made a period of work in Madison possible for one of us (E.D.S.).

\section{REFERENCES}

Dalton, H. \& Postgate, J. R. (1969). Effect of oxygen on growth of Azotobacter chroococcum in batch and continuous cultures. Journal of General Microbiology 54, 463-473.

DilwORTH, M. J. (I966). Acetylene reduction by nitrogen-fixing preparations from Clostridium pasteurianum. Biochimica et biophysica acta 127, 285-294.

Drozd, J. \& Postgate, J. R. (1970). Interference by oxygen in the acetylene reduction test for aerobic nitrogen-fixing bacteria. Journal of General Microbiology 6o, 427-429.

Hardy, R. W. F., Holsten, R. D., JaCkson, E. K. \& Burns, R. C. (I968). The acetylene-ethylene assay for nitrogen fixation: laboratory and field evaluation. Plant Physiology 43, I I 85-I 207.

Postgate, J. R. (I969). Discussion: Royal Society discussion meeting on nitrogen fixation. Proceedings of the Royal Society of London B I72, 355.

Schöllhorn, R. \& Burris, H. ( 1967 ). Acetylene as a competitive inhibitor of nitrogen fixation. Proceedings of the National Academy of Sciences of the United States of America 58, 2 I 3-2 16.

SpIFF, E. D. \& ODU, C. T. I. (1972). An assessment of non-symbiotic nitrogen fixation in some Nigerian soils by the acetylene reduction technique. Soil Biology and Biochemistry 4, 7 I-77.

Strandberg, G. W. \& Wilson, P. W. (1967). Molecular $\mathrm{H}_{2}$ and the $\mathrm{pN}_{2}$ function of Azotobacter. Proceedings of the National Academy of Sciences of the United States of America 58, 1404-1409.

Stewart, W. D. P., Fitzgerald, G. P. \& Burris, R. H. (1967). In situ studies on nitrogen fixation using the acetylene reduction technique. Proceedings of the National Academy of Sciences of the United States of America 58, 2671-2678. 